\title{
Posterior Horn Cell
}

National Cancer Institute

\section{Source}

National Cancer Institute. Posterior Horn Cell. NCI Thesaurus. Code C12640.

Neurons in the posterior (dorsal) horn of the spinal cord whose cell bodies and processes are confined entirely to the central nervous system. They receive collateral or direct terminations of dorsal root fibers. They send their axons either directly to anterior horn cells or to the white matter ascending and descending long itudinal fibers. 